\title{
First Cousin
}

National Cancer Institute

\section{Source}

National Cancer Institute. First Cousin. NCI Thesaurus. Code C71411.

A child of your aunt or uncle. 